\title{
Challenges and Customer Perception on E-Zwich Patronage in Rural Banks in Ghana
}

\author{
Francis Osei $^{1}$, Ofori Daniel ${ }^{2}$, Elizabeth Serwaa Boateng Koomson ${ }^{3}$, Alfred Atakora ${ }^{1}$, \\ Poku Julia Agyapong ${ }^{1}$ \\ ${ }^{1}$ Department of Marketing, School of Business, Kumasi Technical University, Kumasi, Ghana \\ ${ }^{2}$ Department of Entrepreneurship and Finance, Faculty of Entrepreneurship and Enterprise Development, Kumasi Technical University, \\ Kumasi, Ghana \\ ${ }^{3}$ Department of Procurement and Supply Chain Management, School of Business, Kumasi Technical University, Kumasi, Ghana
}

\section{Email address:}

oseifrancis1234@gmail.com (F. Osei), ofori006@yahoo.com (O. Daniel), milizsaga@gmail.com (E. S. B. Koomson), aifredatakora@hotmail.com (A. Atakora), Juoevab5@gmail.com (P. J. Agyapong)

\section{To cite this article:}

Francis Osei, Ofori Daniel, Elizabeth Serwaa Boateng Koomson, Alfred Atakora, Poku Julia Agyapong. Challenges and Customer Perception on E-Zwich Patronage in Rural Banks in Ghana. European Business \& Management. Vol. 7, No. 3, 2021, pp. 85-94.

doi: $10.11648 /$ j.ebm.20210703.14

Received: May 28, 2021; Accepted: June 11, 2021; Published: June 30, 2021

\begin{abstract}
Ghana's banking sector and financial services, in general, have seen major significant technological. The implementation of e-ZWICH in Ghana in 2008 was welcomed with great enthusiasm as exciting news that would help the country transition to a cashless economy. Many Ghanaians signed up for the e-ZWICH, the first biometric payment system. After several years, it appears that interest and patronage have declined dramatically. The study investigated challenges and customer perception on E-zwich patronage in Rural Banks. The purpose of the study is to investigate the adoption and sustainability of E-Zwich service in Ghana. To achieve the purpose of the study a descriptive research design was adopted, using the quantitative approach and the administration of questionnaires to 349 respondents in the data collection process using convenience sampling. In this research, Statistical Package for Social Sciences (SPSS) was employed, whereas Structural Equation Modelling (SEM) technique using smart Partial Least Square (PLS) software version 3.0 was also employed. Two assumptions were made by way of hypotheses. The findings of the study revealed that in the comparison of patronage of Ezwich have positive impact on customer perception and E- zwich challenges. The study finds observed that there is a significant positive relationship between patronage of E-zwich on customer perception and E- zwich of challenges judging from the results of the respondents. The study recommends that, in order to increase patronage of e-ZWICH, GhIPSS should intensify their education on how to operate the stand-alone machine. Measures such as sensitization workshops should be organized by the GhIPSS to encourage Ghanaian companies and individuals and in particular the rural folks to patronize the service. Banks and other non-bank financial institutions should show interest and take up e-ZWICH as a core product. Financial institutions should step-up their customer relations in order to motivate and encourage current customers to continue to patronize the service.
\end{abstract}

Keywords: Challenges, Customer Perception, E-Zwich, Patronage, Rural Banks and Ghana

\section{Introduction}

There are so many contrasting features of different local contexts and this has triggered shifts in the adoption and development of electronic commerce (e-commerce) in various parts of the world $[35,9]$. The growth of e-commerce in Ghana is influenced by attitudes towards the use of electronic money (e-money), institutional trust and the level of education [7, 13, 45]. Year after year, the use of the internet by Ghanaians is growing and there are open doors for the use of e-commerce. While internet usage in Ghana is on the rise, its use is focused only on the cities, leaving a limited population of Ghanaians aware of internet transactions [7,13].

In the modern era of the world, business transactions have 
become the order of the day. The movements of money through these electronic media have brought improvement in business transactions and made fast, safe, and convenient. Goods and services transactions in Ghana are marked by long distances, long queues, and arm robbery, mainly or usually impacting market processes and eventually economic growth Boampong, Twenewaa \& Antwi, [14]. There will be damage notes too that need to be re-printed and this will also affect economic development. Some of the headaches and strains that most Ghanaians and businesses face are the settlement of energy bills, goods and services payments, and money transfer, resulting in a reduction in company operations and generating tremendous debt for most utility providers. There is also under-development in our payment and clearing system in the country Ghana (Boampong \& Twenewaa, Antwi, [14].

The challenges confronting e-commerce and thus epayment are close to the Ghana e-zwich brand. The Ghana Interbank Payment and Settlement System (GhIPSS), a subsidiary of the Bank of Ghana, has been granted the single authority to introduce the biometric payment system, widely known as e-zwich, efficiently and effectively in the nation (ghipss. net). The payment system is a creative way to improve Ghana's connectivity to banking and retail services (Awiagah, Kang \& Lim, [10, 35]. A person does not need to be an account holder of a bank before acquiring the E-Zwich smart card. E-zwich operations have been authorized to all banks in Ghana, including rural banks, to provide the Ghanaian community with quality e-zwich services. (banked and unbanked) so that rural citizens, including those in the cities, are still aware of the product and conduct business electronically, but most people are not aware of the product and prefer to use credit cards from banks and still continue to use the conventional form (physical cash) of transacting business with banks.

The Ghanaian banking sector after the liberalisation has operated in a relatively stable environment, however, with the E-zwich, the industry is characterized by dramatically aggressive competition. These competitions have made banks in Ghana adopted new technologies such as E-zwich to make the banking process faster and easier whilst satisfying the needs of the customers. Others explained that the cost of acquiring the internet facility, computers and even the security of E-zwich transactions are very high or expensive for the average Ghanaian rural bank to incur at the expense of other expenditure.

Despite the introduction of these E-zwich facilities in rural bank in Ghana, clients still opt for the traditional way of banking. They have not taken full advantage of such facilities. This low or non-utilization coupled with the reduction in staff numbers has resulted in overcrowding in the banking halls, bringing in its wake, unnecessary pressure on the few staff even as it wastes clients' time. Therefore, the study purports to investigate the prospects and challenges of ezwich adoption in Ghana and to provide recommendation for enhancing its sustenance. The main purpose of the study is to investigate the adoption and sustainability of in Ghana,
Onuman et al [40].

The study is very importance because electronic payment systems in Ghana are now gaining familiarity now a days and E-Zwich which is the first national biometric payment that has been implemented in Ghana by the Bank of Ghana. The study will help Bank of Ghana and GhIPSS the service providers of this electronic payment systems to know how Ghanaians are adopting the e-Zwich services in their daily transactions.

\section{Literature Review}

This study will review literatures previously done by other researchers and also discusses topics related to the information on E-banking.

\subsection{Banking Overview}

The business of banking is to accept deposit and withdrawal to consumers and businesses [21, 27, 36, 55, 42]. The banking institution provides services such as checking accounts for payments and purchase of goods and services, time deposits, savings accounts. The purpose of saving money is for future transactions. Banks have other services to their clients and businesses that is giving out loans and credit to support customer's business activities, management of cash and foreign exchange transactions. The core business of a bank is to collect, receives, transfers pays, lends and exchanges, invests, and safeguards money for customers. There are financial institutions which render similar services like the banks, some of those institutions are investment companies, investment banks, finance companies, pension funds, insurance companies, mortgage houses, security brokers and dealers and real estate and investment trust [18, $20,21,27,36,55,42]$. There are two fundamental purpose of banking credit cards and checking accounts. Banks are such that, they serve important services in the free market economy, and support businesses. The banking services came to solve the problem of barter. Additionally, banks are the main financial intermediaries which encourage money creation or supply of money in an economy for growth. Activities of financial intermediary engineer the flow of from the surplus unit to deficit unit or to support investors for economic growth.

\subsection{The Evolution of E-Banking}

The newly tested electronic banking device was money transfer through telegraph by Western Union based US in the year 1800 (Liberti et al, [32]. Wiring money through electronic transfer became the main medium for the banks which have been in existence over 100 years. It grows to a time when reporting of a balance was assured through modem and dial up a host to assess the account balance information, which can also be printed out at the same time. However, the process was advanced whereby the account transaction can be downloaded and export to user's accounts $[46,50,11,34]$. The computer system also gives chance to 
user to withdraw cash allowing them to have total control of their funds. Electronic medium for cash transaction is something so important in this era of technological advancement, this has increased information reporting in electronic banking. Electronic payments have brought improvement in cash forecasting, lowering payment cost in addition with processing of account receivable and payables. With regards to the embracement of technology and it effect on electronic banking, is now on the increase. This has raised competition in the banking environment [46, 50, 11, 34].

There have been adoption of technology and in Ghana it started with the use office automation, fax and telephone services, this have been existence and now electronic banking. This has diversified and brought changes in the way business transactions arse conducted. In the banking industry in Ghana, the use of technology began with personal computer (PC) at the back office and teller services this grew and accepted by customers and later networking for a branch and interbranch networks. This made it one bank because no matter your branch you can access your account, withdraw and deposit everywhere provided there is a branch available. Also, the introduction of automated teller machines ATM which reduces the banking halls congestion increased the competition level of the banks. So now all the banks have ATM with only few operating visa and master card applications [47, 50, 11, 34, 53]. The pioneers of this electronic banking exercise are the Colonial banks such as Standard Chartered and Barclays banks in Ghana. Majority of the banks which delayed in ATM implementation lost many customers and they could not survive in the competition at that period (Shahab et al, [46]. The establishment of ATMs was able to entrench the single branch philosophy in Ghana, through networking so customers are able to carry out their transaction without visiting their branch $[8,26,17,40,51,31]$.

Additionally, the introduction of "Sika Card' developed to the e-banking, cash is loaded on the card electronically by Social Security Bank (SSB) same as Societe Générale in the year, 1997. Standard Chartered Bank also introduced the debit card which integrated the ATM, and the coming of ECard by Ecobank, Trust Bank and the Merchant Bank. The ECard is a form of online banking for customer's convenience, whatever that transpire in one's account are reflected automatically online. To improve customer's convenience, the banks further came out with additional benefits such as ebanking termed as personal computer (PC) it's a kind of banking service innovation. I come with proprietary software to corporate clients to visit their account through the Website, Fatima [19]. Most of the pioneers in PC banking services are GCB, Barclays, Stanbic, Standard Chartered, and Ecobank Ghana, this was to increase customer convenience and time. This did not end there, but telephone banking also evolved which main aim is to introduce to customers the products the banks have and other available services such as: requesting cheque book, bank statement, complaints and other enquiries needed by customer $[8,26,17,40,51,31]$. Furthermore, the introduction of mobile banking through the use of mobile phones which have made banking much more-easier and it has also incorporated the non-bank customers and the rural folks are now on board. Consequently, mobile phone usage in the country increased extensively and individuals were comfortable using it as a platform for all business transaction, and SMS banking, which motivated the banks to introduce mobile banking package, for customer convenience.

\subsection{Challenges of E-Zwich}

Since ICT is boosting service delivery and increasing rivalry among financial institutions, countless research on various electronic products and how to improve them for prospective clients have exploded in recent years. As a result, the problems of electronic payments have been extensively researched in recent years. E-banking, offers a lot of advantages through speed, improved efficiency and convenience [43, 29, 17, 3, 38]. Though the use of internet is a kind public network ensuring privacy and security issues. Though the internet supports the fastness of business but it carries some risk to the individual as well as financial institutions. In spite of those risks, management are able to ensure risk mitigation programmes. To ensure an efficient and effectiveness in electronic banking, requires a good networking environment for strong signal to enhance its performance. This can be done through electronic devices, thus, telephones lines, personal computers embedded computer chips, wireless technology, interactive television equipment's and many others. This is the main platform to facilitate the transactions between the banks, corporations and the customers, Sledgianowski et al, [49].

These devices, informational or transactional, help the facilitation and interaction between the bank and the consumer $[43,29,17,3,38,49]$. The use of such devices is synonymous with a lot of threats, but not all are vulnerable. It should be remembered that the internal assaults, in conjunction with contractors and any of the workers who may have allowed access to sensitive computing services one way or another, are probably the most detrimental facets of the bank 's staff. An internal intruder, though, can explicitly protect access to value conversion networks through a mixture of thorough knowledge of the bank's practices and procedures. [15, 4, 54, 41]. This may exploit trusted relationships among networked systems by gaining a level of access which may permit him to circumvent established security controls based on the support of a third party to launch an attack. This may lead to the fraudster to embark on unauthorised transfer of funds and assets out of management knowledge, Yulianto, \& Solikhah, [54].

Against this background the banks should consistently evaluate and review and make sure the internal security is well secured and tight, to avoid unexpected happenings from bad employee or staff. In developing an efficient money transfer system is coming with so many problems Reddy et al, [44]. Some of the problems are power fluctuations, infrastructural deficiency, unstable communication link, which is more common in developing countries and Ghana is not an exception. Moreover, the communication path is not physical and there is a number of eavesdrops and 
interferences of network [15, 4, 54, 41]. This calls for intervention by the government to assist in provision of stable power supply telecommunication devices. There is a high charge or cost on e-payment terminals (ATMs) therefore the banking legislation should set out standard charges for epayment services. Lack of skillful managers and tools for the end users and client systems. Another problem is the large accumulation of cash in the economy, government must issue legislation that would charge the dominance of cash usage on electronic payments. There should be a system for fraud prevention, the banks need to install standby security cameras to identify and confirm the account of the operators. To be successful in this fraud prevention then, they should introduce and install a quality computer wizard to direct and disturb the activities of computer hackers Conti et al, [15]. In the absence of government funding to develop e-banking, central banks should be active in public awareness campaigns and increasing infrastructural issues, and reports must be submitted to relevant government agencies for redress Wang, Cho, \& Denton [52].

\subsection{Empirical Review}

Over three decades we have witnessed several studies in electronic banking scheme. Several of those studies centered on technical advancement in electronic distribution networks that have made a positive contribution to the provision of ebanking services and the development of the banking industry in Ghana [39, 16, 33, 1, 53]. Anane [5] conducted a study on knowledge and utilization of E-Banking facilities with regards to Ghana Commercial Bank. The outcome was that there was a high level of awareness among the customers, however, utilization of E-Banking was low as a results of poor internet accessibility at home, delay in issuing of cards among others. Addy, [2] suggested that internet banking is at its early stage of introduction and development as less bank customers are used to using electronic platforms to handle their financial affairs, thus low internet banking adoption; the disappointment with electronic or internet banking is attributed to the high failure rates of novelest products and services deployed. The degree of website usability could contribute to an improvement in the productivity and loyalty of the user to the website, which can have a positive and important impact on customers as well as satisfaction. This would add to an improvement in the use of online banking as it is applied.

An exploratory survey performed by Roy, Balaji \& Kesharwani [44] on internet banking for the Indian economy, the finding was that, relative to public sector banks, private and international internet banks performed well in providing a wider range and more developed internet banking services. This has contributed to the willingness of private and international businesses to please their clients rather than their local public sector peers. Shankar \& Kumari [47] conducted a study on internet banking in India, the result was that, majority of the account holders use internet most frequently, they have some knowledge about the internet banking. But they have not developed the habit deploying those facilities. Awareness of internet banking and its advantages and protection has also been reported as the key factor for consumers' decreased use of internet banking. However, the degree of consumer education, their device and internet skills, energy problems and password theft, and internet infrastructure have been described as major challenges facing the bank in the growth of its online facilities [39, 16, 33, 1, 53]. Overall, a number of studies have found that IT has major positive impacts on the competitiveness of banks, the work of cashiers, financial transactions, bank patronage, distribution of bank services, customer services and bank facilities. They summarized that these have beneficial effects on banking development.

\subsection{Hypothesis Statements}

$\mathrm{H}_{1}=$ There is a significant positive relationship between patronage of E-zwich (PE) and customer perception (CP).

$\mathrm{H}_{2}=$ There exist a significant positive relationship between patronage of E-zwich (PE) and challenges E- zwich of (EC)

\subsection{The Study Conceptual Model}

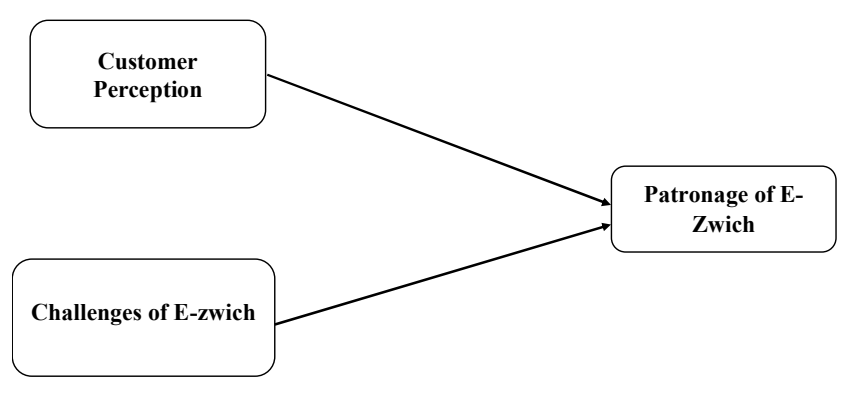

Source: Author own construction (2020).

Figure 1. Theoretical framework.

\section{Methodology}

\subsection{Sampling Strategy and Sample Size}

This study used a quantitative approach, focusing on the objectives, statistical measurements, and numerical analysis of data acquired by questionnaires. The major purpose of quantitative analysis, on the other hand, is to accumulate numerical data and generalize it across groups of people in order to better understand the phenomenon. According to [12, 23] quantitative testing designs might be descriptive (calculated once) or experimental (calculated before and throughout a procedure). The study employed a descriptive analysis design. A descriptive study design is a systematic and analytical analysis in which the investigator does not have direct control of the independent variable unless its indicator has already arisen or may not be manipulated inherently.

The study population targeted customer of rural banks within the area of services with 400 sampled within the Kumasi metropolis of Ghana, and 349 questionnaires were returned for data cleaning and data management. The study utilized Convenience sampling techniques to selecting customers of rural banks in Ghana (Adansi Rural Bank, Amanano Rural Bank, Atwima Kwanwoma Rural Bank Ltd, Atwima Kwanwoma Rural Bank and Amansie West Rural Bank Ltd). 


\subsection{Structure of Questionnaire and Data Management}

In this study, self-administered questionnaires were used to collect data from the respondents. The collected data will be coded, edited and tabulated using the Social Science Statistical Program (SPSS) and smart PLS. The questionnaires for this research were guided by recent work by Issahaku [28] and Kumaga [30]. The questionnaire was in two parts. The first part aimed at the collection of demographic information on the participants. The second part focused on patronage of E-Zwich services provided by the rural banks in Ghana. It gathered information on customer's patronage of E-Zwich services from using E-Zwich services. This was meant to find out whether the challenges and customer perception have influence on patronage of E-Zwich services. The last part is using a five-point Likert scale instrument of $1=$ Strongly Disagree (SD), $2=$ Disagree (D), $3=$ Neutral $(\mathrm{N}), 4=$ Agree (A), and 5=Strongly Agree (SA). which measures challenges and customer perception from the perspective of the individuals.

\section{Demographic Profile of Respondents}

The demographic profile of respondents necessary for the study are presented in the Table 1 below. Respondents have been profiled according to gender, age, academic qualification, and marital status.

Table 1. Demographic Characteristics of the respondents.

\begin{tabular}{llll}
\hline Variables & Categories & Frequency & Percent \\
\hline Gender & Male & 145 & 58.2 \\
& Female & 104 & 41.8 \\
Age & Total & 249 & 100.0 \\
& Up to 30yrs & 60 & 24.1 \\
& 31 to 40yrs & 165 & 66.3 \\
& 41 to 50yrs & 14 & 5.6 \\
Educational status & 51 and Above & 10 & 4.0 \\
& Total & 249 & 100.0 \\
& MSLC/JHS & 7 & 2.8 \\
& SSSCE & 47 & 18.9 \\
& Diploma & 117 & 47.0 \\
Degree & 58 & 23.3 \\
Parital status & Post Graduate & 19 & 7.6 \\
& Others & 1 & .4 \\
& Total & 249 & 100.0 \\
& Married & 46 & 18.5 \\
& Single & 200 & 80.3
\end{tabular}

Source: Field data (2020).

The above table contains the demographic profile of respondents that were engaged for the study. The results showed that out of $249(100 \%)$ respondents, 145 (58.2\%) were males and $104(41.8 \%)$ were females. This shows that majority of the respondents were females, as compared to males. Furthermore, the results showed that $60(24.1 \%)$ of the respondents were up to 30 years, $165(66.3 \%)$ were between 31 to 40years, 14 (5.6) of the respondents were between 41 to 50 years and 10 (4.0) of the respondents were 51 and above. Thus, majority of the respondents were between 31 to 40years, while the least were 51 and above. As regard the educational level of the respondents, those with MSLC/JHS as their highest educational level were 7 (2.8\%). SHS educational level had 47 (18.9\%). Respondents with diploma were 117 (47.0\%), Degree holders were 58 (23.3\%), Postgraduate level had 19 $(7.6 \%)$ and other $1(0.4 \%)$. Finally, the results showed that 47 $(18.5 \%)$ were married, $200(80.5 \%)$ were single, $2(0.8 \%)$ were divorced and $1(0.4 \%)$ was widowed.

\subsection{Analysis and Results of Structural Equation Modelling}

In testing the hypothesis resulting from the theoretical model, Structural Equation Modeling (SEM) was used. In this research, the two-stage approach supported by Anderson and Gerbing [6] was adopted because the precise representation of the reliability of each build is better carried out in two stages to prevent any interaction between measurement and structural models Hair et al., [24].

\subsection{Validity and Reliability Results}

In order to ensure the level of consistency in the measurement of the intended latent construct, a reliability test was carried out. The alpha of Cronbach was used to test the reliability and the results exceeded the acceptable standard $>.70$, showing a high reliability for the instruments adopted Nunnally, [37]. 
Table 2. Construct Reliability and Validity.

\begin{tabular}{|c|c|c|c|c|c|}
\hline Research constructs & Cronbach's alpha & Rho_A & $\mathbf{C R}$ & AVE & Loadings \\
\hline Customer Perception & 0.850 & 0.928 & 0.889 & 0.627 & \\
\hline $\mathrm{CP} 1$ & & & & & 0.883 \\
\hline $\mathrm{CP} 2$ & & & & & 0.931 \\
\hline $\mathrm{CP} 3$ & & & & & 0.558 \\
\hline $\mathrm{CP} 4$ & & & & & 0.553 \\
\hline CP5 & & & & & 0.935 \\
\hline E-Zwich Challenges & 0.874 & 0.924 & 0.900 & 0.644 & \\
\hline EC1 & & & & & 0.822 \\
\hline $\mathrm{EC} 2$ & & & & & 0.821 \\
\hline $\mathrm{EC} 3$ & & & & & 0.822 \\
\hline EC4 & & & & & 0.746 \\
\hline EC5 & & & & & 0.798 \\
\hline Patronage of E-Zwich & 0.969 & 0.970 & 0.975 & 0.866 & \\
\hline PE1 & & & & & 0.914 \\
\hline PE2 & & & & & 0.941 \\
\hline PE3 & & & & & 0.927 \\
\hline PE4 & & & & & 0.938 \\
\hline PE5 & & & & & 0.924 \\
\hline PE6 & & & & & 0.940 \\
\hline
\end{tabular}

Source: Field data (2020).

The Composite Reliability (CR) values were also greater than 0.80 and the Derived Average Variance $>.50$, showing convergent validity where there is agreement between the multiple items measuring a single definition and suggesting sufficient internal consistency of the constructs $[22,25,56]$. The above table shows the specifics of the constructs' reliability, factor loadings, and average variance removed.

Table 3. Discriminant validity.

\begin{tabular}{llll}
\hline & CUSTOMER PERCEPTION & E- ZWICH OF CHALLENCES & PATRONAGE OF E-ZWICH \\
\hline CUSTOMER PERCEPTION & 0.792 & & \\
E- ZWICH OF CHALLENGES & 0.713 & 0.802 & 0.931 \\
PATRONAGE OF E-ZWICH & 0.777 & 0.704 & \\
\hline
\end{tabular}

In order to measure the degree to which the constructs differed and to evaluate the freedom of measurement model of a construct from redundant objects, discriminant validity was also used. In particular, the measure was assumed to have discriminant validity if the items in a construct were more closely correlated with each other than with items measuring other constructs. A scale should not be closely associated with the calculation of a separate construct in this light Babin and Zikmund, [55]. Scholars such as Fornell and Lacker [22] postulate that the AVE's square root should be greater than the correlation between the construct and the other constructs, and this research is in line with this claim because, for each construct, all the constructs met the discriminant validity with the AVE greater than the square correlation with the other constructs as shown in the above table. This is the matrix for inter-construct correlation.

Table 4. Total effects.

\begin{tabular}{|c|c|c|c|}
\hline & CUSTOMER PERCEPTION & E- ZWICH OF CHALLENCES & PATRONAGE OF E-ZWICH \\
\hline CUSTOMER PERCEPTION & & & 0.559 \\
\hline E- ZWICH OF CHALLENGES & & & 0.306 \\
\hline PATRONAGE OF E-ZWICH & & & \\
\hline
\end{tabular}

The positive reading of all the variables confirm that the model fits the data perfectly.

Table 5. Structural model from the hypothesized relationships.

\begin{tabular}{llllll}
\hline Study's hypothesis & Hypothesis & Path Coefficient & T Statistics & P Values & Supported/Rejected \\
\hline CP -> PE & H1 & 0.559 & 8.576 & 0.000 & Supported \\
E C -> PE & H2 & 0.306 & 4.836 & 0.000 & Supported \\
\hline
\end{tabular}

Note: $\mathrm{CP}=$ Customer Perception; $\mathrm{Pe}=$ Patronage of E-Zwich; $\mathrm{Ec}=\mathrm{E}-$ Challenges of E-Zwich. ${ }^{*}$ Significance at $\mathrm{p}<0.05 ; * *$ Significance at $\mathrm{p}<0.01 ; * * *$ Significance at $\mathrm{p}<0.001$. 


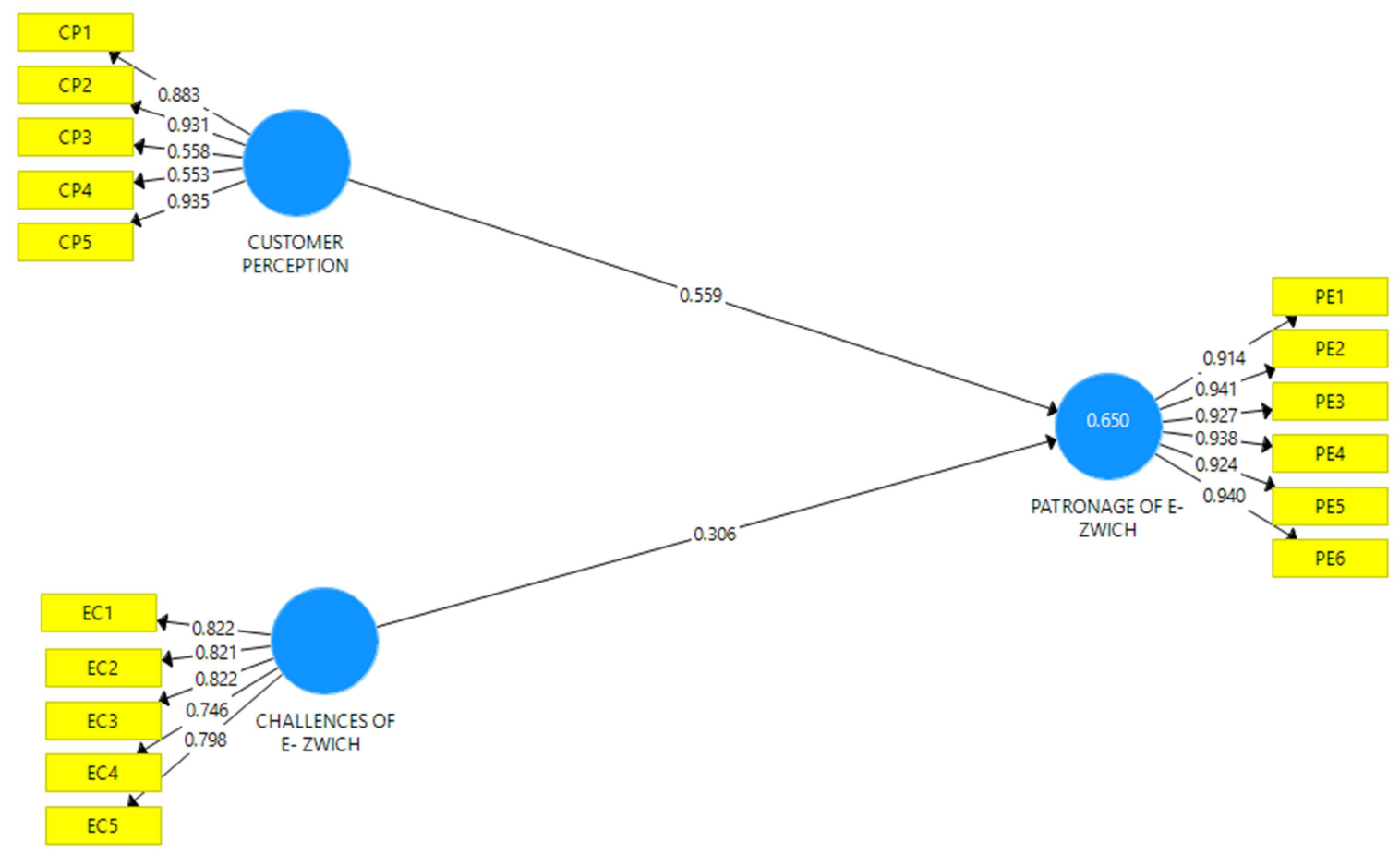

Figure 2. Regression weights of Path Analysis of proposed Structural Model.

\subsection{Discussion of the Study}

The summary of the hypothesized relationships was done according to the conceptual model presented in the path diagram analysis in Figure as well as outcome from H1: There is a significant positive relationship between patronage of E-zwich (PE) and customer perception (CP). Considering the results that was generated from the study, the predicted significant positive relationship between patronage of Ezwich (EC) and customer perception (CP) was supported. This therefore, confirms the first hypothesis (H1) and its implication is that patronage of E-zwich service in Ghana banks has a greater impact on customer perception of the respondents. Consumers will develop a positive customer perception towards patronage of E-zwich Ghanaian banks. The path coefficient of was 0.559 , t-value was 8.576 , where significance level is $t \geq 1.65$, and $p$ value of 0.000 at a highly significant level of $\mathrm{p}<0.05, \mathrm{p}<0.001$ exhibiting a high correlation between the two variables of interest. This is in line with Addy, (2016) who suggested that internet banking is at its early stage of introduction and development as less bank customers are used to using electronic platforms to handle their financial affairs, thus low internet banking adoption; the disappointment with electronic or internet banking is attributed to the high failure rates of novelest products and services deployed.

$\mathrm{H} 2$ : There exist a significant positive relationship between patronage of E-zwich (PE) and challenges of E- zwich (EC). Similarly, the significant positive relationship posited initially between patronage of E-zwich (PE) and challenges of Ezwich users was supported by the findings of the study. Taking into consideration the path coefficient of 0.306 , t-value of 4.836 significant at $t \geq 1.65$, and $p$ value of 0.000 at a high significance level of $p<0.05$ shows a high correlation. This is evident that customers will patronize E-zwich service only if it has low challenges. Therefore, consumers will patronize Ezwich service save more of banks evolving from developed countries of their preference than they would from developing countries. Hypothesis two (H2) of the study was therefore supported. This is in accordance with (Andoh, 2014; Boachie [13], who claim that attitudes about the use of electronic money (e-money), institutional trust, and educational attainment all influence the expansion of e-commerce in Ghana. It also backs up the claims made by (Reddy, Reddy, 2015; Jindal, 2016; Agwu,[3]; Solangi, [50]; Okifo \& Igbunu,[38]; Sidhu, Sharma \& Punj, [48] that E-banking provides numerous benefits in terms of speed, efficiency, and convenience. Finally, as Ali and Al-Jabri (2011) point out, epayments have several problems, which is why most cultures continue to rely on the old method of conducting business although online banking is readily available.

\section{Conclusion}

The main purpose of the research was to examine the challenges of E-Zwich and customer perception of E-zwich on consumer patronage of E-zwich delving from the perspectives of customers. In order to achieve the set objectives, a quantitative method was adopted and questionnaires were utilized to obtain data from 200 customers and 49 non-customers. Furthermore, this study verified that challenges of E-Zwich and customer perception are key variable in consumer patronage of E-zwich in rural banks in Ghana.

In short, industries and businesses all over the world use the internet. This is because, by providing an affordable and direct 
way to share information and sell or purchase goods or services, electronic commerce is now believed to hold the promise of a commercial revolution. This marketplace movement set in motion a revolution in the banking sector to have a payment mechanism that is compliant with the electronic marketplace's demands. In view of this, e-ZWICH was founded by GhIPSS in 2008 primarily to promote a cashless society in Ghana. Payments for goods and services are characterized by long queues, long-distance travel, armed robbery, waste of time and high business transaction costs, which typically impact economic growth. In view of this, Ezwich has been implemented to fill these gaps in banking industries. The device in the Rural Bank is faced with several challenges. The respondents and data providers described these challenges. In order of significance, the general challenges include connection failure, frequent breakdown of equipment, sluggish service delivery process and long queues. Service providers have also found problems such as network security concerns, impatient customers, customer card weaknesses due to unsafe handling, and poor bank benefits due to banks running the service on behalf of GhIPSS.

\subsection{Recommendations}

GhIPSS should intensify its training on how to run a standalone machine in order to increase the patronage of e-zwich. Measures such as sensitization workshops should be organized by the GhIPSS to promote the patronization of the service by Ghanaian businesses and individuals and in particular, rural citizens. GhIPSS should build alternative network lines in order to boost connectivity, rather than relying solely on telecommunications networks that have frequent connection failures. Banks and other non-bank financial institutions should be involved and e-zwich as a core product should be taken up. In order to inspire and enable existing customers to continue to patronize the service, financial institutions should step-up their customer relations. In particular, rural banks should be interested in the provision of e-zwich services in order to get them to rural people's doorsteps. Banks and other financial institutions should embark, in their own way, on educational campaigns to raise public awareness of the benefits of e-zwich. This will help establish a cashless society, reduce the incidence of card fraud and among other things, minimize long queues in business transactions. Educational institutions can help to increase e-ZWICH patronage by allowing students to pay fees through e-zwich and to work with GhIPSS and financial institutions in order to erect stand-alone e-zwich machines on their campuses. Enterprises should also acquire a POS device to allow consumers to use their e-zwich cards to pay for products and services. It is important that all stakeholders do everything possible to ensure that the e-zwich does not become one of the many inventions that could not stand the test of time, such as the SG-SSB bank's 'sika-card.'

\subsection{Future Research}

This investigation was limited to a survey conducted on some Rural Banks in Ghana, as it was most available and within the researcher's budget. The study can however be extended in the future to include other heavily populated areas such as Greater Accra, Tema, Takoradi and Tamale. This will give the research goals a wider perspective. Future research on this relevant issue may also include some new moderating factors, such as tradition and culture, consumer psychographics, which contribute significantly to consumer attitude and perception and also, evaluate the e-banking strategy for selected banks in Ghana.

\section{References}

[1] Addai, B., Ameyaw, B., Ashalley, E., \& Quaye, I. (2015). Electronic banking and customer satisfaction: Empirical evidence from Ghana. Journal of Economics, Management and Trade, 1-8.

[2] ADDY, D. N. (2016). Adoption of electronic banking in the ghanaian the banking system: A Case Study of Ghana Commercial Bank (Doctoral dissertation).

[3] Agwu, P. E. (2018). Analysis of the impact of strategic management on the business performance of SMEs in Nigeria. Academy of Strategic Management, 17 (1).

[4] Allodi, L., \& Massacci, F. (2017). Security events and vulnerability data for cybersecurity risk estimation. Risk Analysis, 37 (8), 1606-1627.

[5] Anane, R. (2019). Knowledge and utilisation of e-banking facilities in the National Investment Bank in Central Region of Ghana (Doctoral dissertation, University of Cape Coast).

[6] Anderson, J. C., \& Gerbing, D. W. (1988). Structural equation modeling in practice: A review and recommended two-step approach. Psychological bulletin, 103 (3), 411.

[7] Andoh, P. (2019). From pension to wellbeing: A study of retirement income and wellbeing of retirees in Ghana.

[8] Asante-Gyabaah, G., Danquah, E. O. A., \& Tetteh-Wayoe, D. K. (2015). Assessing the Impact of the ATM in Delivering Service in the Banking Industry. A case of GCB Bank Ltd. European Journal of Business and Management, 7 (20), 40-53.

[9] Awa, H. O., Ojiabo, O. U., \& Emecheta, B. C. (2015). Integrating TAM, TPB and TOE frameworks and expanding their characteristic constructs for e-commerce adoption by SMEs. Journal of Science \& Technology Policy Management.

[10] Awiagah, R., Kang, J., \& Lim, J. I. (2016). Factors affecting ecommerce adoption among SMEs in Ghana. Information Development, 32 (4), 815-836.

[11] Barker, R., \& Schulte, S. (2017). Representing the market perspective: Fair value measurement for non-financial assets. Accounting, Organizations and Society, 56, 55-67.

[12] Bettany-Saltikov, J., \& Whittaker, V. J. (2014). Selecting the most appropriate inferential statistical test for your quantitative research study. Journal of Clinical Nursing, 23 (11-12), 1520-1531.

[13] Boachie, E. (2016). Importance of E-Commerce on Small and Medium Enterprises (SMEs) In Ghana. International Journal of Trend in Research and Development, 3 (4). 
[14] BOAMPONG, A., TWENEWAA, M., ANTWI, P., SHEILADAAH, K., \& OWUSU, O. (2016). USER ACCEPTABILITY OF ELECTRONIC PAYMENT SYSTEM AND PAYMENT PROBLEMS IN KUMASI: (A CASE STUDY IN THE KUMASI METROPOLIS).

[15] Conti, M., Kumar, E. S., Lal, C., \& Ruj, S. (2018). A survey on security and privacy issues of bitcoin. IEEE Communications Surveys \& Tutorials, 20 (4), 3416-3452.

[16] Dauda, S. Y., \& Lee, J. (2015). Technology adoption: A conjoint analysis of consumers' preference on future online banking services. Information Systems, 53, 1-15.

[17] Enu, P., \& Gberbi, J. T. (2015). Effect of Information and Communication Technology (ICT) on the Delivery of Banking Services in Ghana: A Case Study of Zenith Bank Ghana Limited. Global Journal of Management Studies and Researches, 2 (2), 60-82.

[18] Farooqui, K. D. The effect of different irrigation regimes (through drip irrigation system) on growth, yield and quality of newly evolved apple varieties Firdous and Sunhari (Doctoral dissertation, SKUAST-K).

[19] Fatima, R., Yasin, A., Liu, L., Wang, J., Afzal, W., \& Yasin, A. (2019). Improving software requirements reasoning by novices: a story-based approach. IET Software, 13 (6), 564-574.

[20] Felix, P. (2018). Prospects and challenges of electronic banking in Ghana: The case of Zenith Bank, Sunyani. IJAMEE.

[21] Felix, R. (2017). Service quality and customer satisfaction in selected banks in Rwanda. Journal of Business \& Financial Affairs, 6 (1), 1-11.

[22] Fornell, C., \& Larcker, D. F. (1981). Structural equation models with unobservable variables and measurement error: Algebra and statistics.

[23] Gravetter, F. J., \& Forzano, L. A. B. (2018). Research methods for the behavioral sciences. Cengage Learning.

[24] Gronemus, J. Q., Hair, P. S., Crawford, K. B., Nyalwidhe, J. O., Cunnion, K. M., \& Krishna, N. K. (2010). Potent inhibition of the classical pathway of complement by a novel C1q-binding peptide derived from the human astrovirus coat protein. Molecular immunology, 48 (1-3), 305-313.

[25] Hair, J. F., Sarstedt, M., Pieper, T. M., \& Ringle, C. M. (2012). The use of partial least squares structural equation modeling in strategic management research: a review of past practices and recommendations for future applications. Long range planning, 45 (5-6), 320-340.

[26] Hananu, B., Abdul-Hanan, A., \& Zakaria, H. (2015). Factors influencing agricultural credit demand in Northern Ghana. African Journal of Agricultural Research, 10 (7), 645-652.

[27] Humphrey, D. (2016). Negative interest rates and the demand for cash. Journal of Payments Strategy \& Systems, 9 (4), 280 289.

[28] Issahaku, H. (2012). Challenges of electronic payment systems in Ghana: The case of e-ZWICH.

[29] Jindal, S. (2016). Study of E-Banking Scenario in India. International Journal of Science and Research (IJSR), 5 (12), 680-683.

[30] Kumaga, D. (2010). The Challenges of Implementing Electronic Payment Systems. The Case of Ghana's E-zwich
Payment System.

[31] Kyeremeh, K., Prempeh, K. B., \& Afful Forson, M. (2019). Effect of Information Communication and Technology (ICT) on the Performance of Financial Institutions (A Case Study of Barclays Bank, Sunyani Branch).

[32] Liberti, J. M., \& Petersen, M. A. (2019). Information: Hard and soft. Review of Corporate Finance Studies, 8 (1), 1-41.

[33] Lin, F. T., Wu, H. Y., \& Tran, T. N. N. (2015). Internet banking adoption in a developing country: an empirical study in Vietnam. Information Systems and e-Business Management, 13 (2), 267-287.

[34] Lin, H., Liu, W., Zeng, H., Pu, C., Zhang, R., Qiu, Z.,... \& Shu, W. (2016). Determination of environmental exposure to microcystin and aflatoxin as a risk for renal function based on 5493 rural people in Southwest China. Environmental science \& technology, 50 (10), 5346-5356.

[35] Mahajan, P., \& Agarwal, M. (2015). Exploring the Potential of E-Commerce in the Digital Age: Challenges and Opportunities for Commerce Education. IUP Journal of Information Technology, 11 (4).

[36] Mori, M., \& Zimmer, T. (2015). Mobilizing Banking for Indonesia's Poor. Innovations: Technology, Governance, Globalization, 10 (1-2), 95-124.

[37] Nunnally, J. C. (1978). An overview of psychological measurement. Clinical diagnosis of mental disorders, 97-146.

[38] Okifo, J., \& Igbunu, R. (2015). Electronic Payment System in Nigeria: Its Economic Benefits and Challenges. Journal of Education and practice, 6 (16), 56-62.

[39] Oni, A. A., Adewoye, O. J., \& Eweoya, I. O. (2016). E-banking users' behaviour: e-service quality, attitude, and customer satisfaction. International Journal of Bank Marketing.

[40] Onuman, F., \& Christopher, D. B. (2016). Prospects and Challenges of Electronic Banking in Société Generale Ghana Limited: Evidence from Accra Metropolis. Prospects, 7 (24).

[41] Price, J. C., \& Forrest, J. S. (2016). Airport Emergency Planning, Part II: Emergency Management Functions. Practical Airport Operations, Safety, and Emergency Management, 427.

[42] Prodanova, J., San-Martín, S., \& Jiménez, N. (2015). The present and the future of m-banking according to spanish bank customers. Universia Business Review, (46), 94-117.

[43] Reddy, D. K., \& Reddy, M. S. (2015). A study on customer's perception and satisfaction towards electronic banking in Khammam district. Journal of Business and Management, 17, 20-27.

[44] Roy, S. K., Balaji, M. S., Kesharwani, A., \& Sekhon, H. (2017). Predicting Internet banking adoption in India: a perceived risk perspective. Journal of Strategic Marketing, 25 (5-6), 418-438.

[45] Sakoe, M. A. J. (2015). The Effects of Electronic Banking on Financial Services in Ghana.

[46] Shahab, S., Clinch, J. P., \& O'Neill, E. (2018). Timing and distributional aspects of transaction costs in Transferable Development Rights programmes. Habitat International, 75, 131-138. 
[47] Shankar, A., \& Kumari, P. (2016). Factors affecting mobile banking adoption behavior in India. The Journal of Internet Banking and Commerce, 21 (1).

[48] Sidhu, L. S., Sharma, J., Shivani, S., \& Punj, P. (2015). Ebanking (benefits and challenges in an emerging economy). COMPUSOFT: An International Journal of Advanced Computer Technology, 4 (4).

[49] Sledgianowski, D., Gomaa, M., \& Tan, C. (2017). Toward integration of Big Data, technology and information systems competencies into the accounting curriculum. Journal of Accounting Education, 38, 81-93.

[50] Solangi, B., Talpur, U., Shaikh, S. S., Mushatque, T., \& Channa, M. A. (2019). Relationship Marketing as an Orientation to Customer Retention: Evidence from Banks of Pakistan. International Business Research, 12 (7), 133-140.

[51] TWUMASI FORSON, D. E. N. N. I. S., DENNIS, A. K., NANA, N., STEPHEN, J. F., \& ABABIO, A. (2016).
IMPACT OF ONLINE BANKING IN GHANA (A CASE STUDY OF STANDARD CHARTERED BANK, HARPER ROAD BRANCH).

[52] Wang, M., Cho, S., \& Denton, T. (2017). The impact of personalization and compatibility with past experience on ebanking usage. International Journal of Bank Marketing.

[53] Warszawski, T., \& Bailis, P. (2017, May). Acidrain: Concurrency-related attacks on database-backed web applications. In Proceedings of the 2017 ACM International Conference on Management of Data (pp. 5-20).

[54] Yulianto, A., \& Solikhah, B. (2016). The internal factors of Indonesian Sharia banking to predict the mudharabah deposits. Review of Integrative Business and Economics Research, 5 (1), 210.

[55] Zikmund, W. G., Babin, B. J., Carr, J. C., Adhikari, A., \& Griffin, M. (2016). Business research methods: A South-Asian perspective. Cengage Learning. 